\title{
Initial Assessment and Monitoring of Nutritional Status and Malignant Pain in Lung Cancer Patients
}

1 Sandra Karabatić

1 Andreja Šajnić

2 Snježana Čukljek

1 Ivana Lukić Franolić

1 Sanja Pleština

1 Miroslav Samaržija

1 Department for respiratory diseases Jordanovac, University Hospital Center Rebro, Zagreb, Croatia

2 University of Applied Health Sciences, Zagreb, Croatia

Article received: 22.06 .2020 .

Article accepted: 17.07.2020.

https://doi.org/10.24141/2/4/2/1

Author for correspondence:

Sandra Karabatić

Department for respiratory diseases Jordanovac, Univer-

sity Hospital Center Zagreb,

Kišpatićeva 12, Zagreb, Croatia

E-mail: udruga.jedra@gmail.com

Keywords: lung cancer, nutrition status, pain, a component of nursing documentation

\section{Abstract}

Introduction. Lung cancer is a complex disease and requires a multidisciplinary approach to achieve the best results in treatment, to increase the survival rate while preserving the quality of life of the sufferer. The nutritional status of the patient is an important factor affecting outcome and recovery from disease or injury. We question whether there is a link between nutritional status and malignant pain in lung cancer patients.

Aim. A prospective trial was conducted to determine the distribution of respondents by frequency of pain according to a validated Visual Analog Scale (VAS), distribution of respondents who reported reduced food intake and distribution of factors that have led to the reduced food intake.

Methods. A prospective trial was conducted at the Department for respiratory diseases Jordanovac, University Hospital Center Zagreb, Croatia, on a sample of patients with advanced non-small cell lung cancer to determine the frequency, characteristics and treatment of chronic malignant pain $(\mathrm{N}=76)$. These are the results from November 2013 to June 2014. For pain assessment, we used a validated VAS. For the identification of patients at risk of malnutrition we used Nutritional risk screening tool (NRS 2002). For a rough estimate of total body adiposity, we measured dermal thicknesses using a standard calliper. Monitoring of patients was documented in the form of nursing documentation. A component of 
nursing documentation was designed to monitor the nutritional status of cancer patients and has been implemented at the Department for respiratory diseases Jordanovac as required documentation. The component included collecting the following data: the stage and type of cancer and treatment, demographic characteristics, age, gender, vital signs, body weight and height, body mass index (BMI), subjective symptoms such as pain, fatigue and nausea, reduction ad rezones of food consumption.

Results. During the study 417 measurements were made: 1) $32,1 \%$ of patients reported reduced food intake, and $67,9 \%$ of respondents indicated that have not reduced their regular diet; 2 ) as a reason for the reduced food intake $37,7 \%$ respondents stated loss of appetite, $31,2 \%$ fatigue and $24,6 \%$ pain; 3) $59,5 \%$ subjects mainly reported absence of pain, while none of the respondents reported the existence of the highest degree of pain.

Conclusion. By regular monitoring of the intensity of the pain we achieved good control in malignant pain management, which is an important data in the assessment of nutritional status. The fact is that poorly controlled pain is present in $24 \%$ of patients and has been the reason for the reduced food intake.

\section{Introduction}

According to the Croatian Cancer Registry, in 2017, 2,232 men and 1,003 women were diagnosed with tracheal, bronchial and lung cancer, with the second being most common cancer in men (17\%) and the third in women (9\%) (1). Worldwide, in 2012 lung cancer occurred in approximately 1.8 million patients and caused an estimated 1.6 million deaths (2). The incidence increased over the years and in 2018 lung cancer occurred in approximately 2.1 million patients and caused an estimated 1.7 million deaths $(2,3)$. Lung cancer refers to malignant diseases that originate from the airways and lung parenchyma. Based on the origin of the cell it is divided into small cell lung cancer (SCLC) and non-small cell lung cancer (NSCLC). In patients with lung cancer, it is necessary to define the cell type before starting with specific and personalized oncological treatment (4-6).
Cancer induces a disorder in cellular function. Thus, altered cells acquire the characteristics of rapid growth and the ability to spread to surrounding tissues in the body. Cancer cells have evolved to be able to face several obstacles, and during this process, they have become extremely resilient. Factors that are difficult to control and are responsible for about 30\% of all cancers are hereditary, environmental or viral. On the other hand, approximately $70 \%$ of cancers are caused by other factors that are directly related to lifestyles, such as smoking, physical inactivity, obesity, dietary composition, and excessive alcohol and opiate consumption $(4,7)$. The symptoms of a malignant disease are often very nonspecific which is one of the reasons for late detection of cancer. Symptoms that occur in patients with lung cancer are dry irritating cough - 50 to $75 \%$, dyspnea - 25 to $40 \%$, chest pain - 20 to $40 \%$, hemoptysis - 20 to $50 \%$ (8$11)$, fatigue, weakness, hoarseness $(12,13)$, pleural effusion - 10 to $15 \%(5,14)$, superior vena cava syndrome, paraneoplastic syndrome and metastasis (5). Haematological disorders are anaemia (haemoglobin $\leq 12 \mathrm{~g} / \mathrm{dL}$ ), which is present in $40 \%$ of patients who are not therapeutically covered and in $80 \%$ of patients who received chemotherapy (15), leukocytosis which is present in $15 \%$ and is most commonly associated with hypercalcemia which is considered a poor prognostic factor in survival $(16,17)$. Thrombocytosis is present in $14 \%$ and is an independent predictor for decreased survival $(18,19)$. The most common coagulation disorders present in patients with lung cancer are Trousseau's syndrome, deep vein thrombosis, thromboembolism, disseminated intravascular coagulation, thrombotic microangiopathy and nonthrombotic microangiopathy (5). Despite all these symptoms and concomitant conditions, it should be noted that one quarter of patients with lung cancer are asymptomatic (20) while symptoms such as loss of appetite and weight are not pathognomonic for lung cancer, therefore further diagnostic testing is needed to detect the disease (8-10).

Patients with lung cancer face several symptoms and side effects that interfere with their daily activities. Side effects negatively affect a patient's quality of life during and after oncology treatment (6) and we divide them into those related to the disease itself and those that are the result of specific oncological treatment. Side effects associated with the disease are fatigue, dyspnea, difficulty swallowing, hemoptysis, pain and cancer anorexia/cachexia. Side effects 
associated with specific oncological treatment are nausea, vomiting, diarrhoea, constipation, alopecia, change in taste or smell, esophagitis, fatigue, anaemia, leukopenia, thrombocytopenia, infections, pain and thigh numbness, skin changes, pain, anorexia/ cachexia (6). The prognosis of survival in patients with NSCLC decreases with the progression of the underlying disease (6) factors that predict mortality include weight loss and Eastern Cooperative Oncology Group (ECOG) Performance Status. Decreased appetite is an indicator of weight loss and a negative predictor of survival in lung cancer patients (21-26).

Factors that lead to reduced intake of nutrients in cancer patients

- Pain is the most stressful and worrying symptom for patients and their families. $80 \%$ of cancer patients are affected by pain. Fortunately, well-controlled pain is possible in most cases. Opioids are the leading therapy for moderate to severe pain and it is very important to provide adequate psychosocial support (27).

- Dyspnea is a common symptom of lung cancer and intrathoracic metastatic disease (28).

- Insomnia is a common and stressful symptom in terminally ill patients. It affects quality of life and may increase the intensity of other symptoms such as pain, anxiety or delirium (28).

- Fatigue (asthenia, weakness) is the most common and typical multidimensional symptom in lung cancer patients that affects the quality of life. In most cases, fatigue is a symptom not promptly diagnosed and treated (28).

- Nausea and/or vomiting are present in most patients due to metabolic abnormalities, opioid administration, pharmacological therapy and brain metastasis (28).

- Xerostomia, also known as dry mouth, has been described as a feeling of dryness in the mouth that makes it difficult to chew and swallow (29), which may be associated with: radiotherapy, chemotherapy, surgery (especially head and neck), drugs (anticholinergics, antidepressants, opioids, anxiolytics, antihistamines, beta-blockers), dehydration and oral infection (30).

- Radiation-induced dysphagia is a common symptom in cancer patients undergoing upper esophageal radiotherapy. These patients are at an increased risk of food aspiration. The initial management dysphagia is an immediate change in diet and food consistency (28).

\section{Anorexia/cachexia}

Anorexia and weight loss are common in patients with lung cancer, they can occur due to the underlying disease or specific oncological treatment (6). Anorexia or loss of appetite may be associated with a tumour-host interaction, loss of taste sensation, dysphagia, stomatitis, gastroparesis, nausea, vomiting, distal intestinal obstruction syndrome, specific oncological treatment, pain and depression. Anorexia leads to reduced food intake, resulting in weight loss which is a bad prognostic sign $(6,28)$.

Cachexia is a hypercatabolic condition defined by accelerated skeletal muscle loss in the context of a chronic inflammatory response that occurs in cancer patients (28). Cachexia consists of weight loss of $\geq 10 \%$ over 6 months, manifested by asthenia and general weakness, changes in physical appearance and mental stress (31-35). Weight loss in patients with cachexia is not only caused by reduced food intake but is also caused by metabolic abnormalities. Metabolic abnormalities lead to an increase in basal energy that results in weight loss in skeletal muscle. Cachexia is defined using a three-stage system: pre-cachexia, cachexia, and refractory cachexia $(34,36,37)$.

Estimation of loss of body weight is often neglected in patients who are obese, edematous or with the expansion of tumours $(34,36,38)$. According to some studies, cachexia occurs in $50 \%$ of cancer patients (regardless of the stage of the disease), and $80 \%$ of patients with an advanced malignant disease (34). The importance of these data is significant because a loss of only $5 \%$ of body weight can significantly worsen the prognosis of cancer patients and shorten overall survival (39). Despite these findings, the problem of malnutrition in hospitals remains largely unrecognized (40). From all the above, it is important to assess and regularly monitor the nutritional status of patients, monitor and record side effects and act accordingly. Accordingly, to the importance of these data at Department for respiratory diseases Jordanovac, UHC Zareb, component of nursing documentation was designed and implemented as mandatory nursing documentation for assessment and regularly monitoring the general condition and nutritional sta- 
tus patients with lung cancer. Data from the component of nursing documentation are analyzed in this paper (41).

The research aimed to determine the distribution of respondents by the frequency of the presence of pain, the distribution of subjects in which reduced food intake was present and to determine the reasons that have led to reduced food intake. The purpose of this paper was to encourage research which would lead to timely intervention in everyday clinical practice when risks of malnutrition occur. Through the observation of malnutrition, we can better assess the possible outcome of therapy and the course of the disease.

\section{Methods}

A prospective trial was conducted at the Department for respiratory diseases Jordanovac, University Hospital Center Zagreb, Croatia, in the period from November 2013 to June 2014, on a sample of patients with advanced non-small cell lung cancer. During this period patients received cancer treatment (chemotherapy) and nutrition support according to current Croatian guidelines $(\mathrm{N}=76)$. This sample represents a deliberately selected sample that corresponds to the patient population of the clinic.

For assessment and regulatory monitoring general condition and nutrition status in these patients, we used the mandatory part of the nursing documentation (41). Patients were informed that their data will be used in an anonymized form and will only be used for this paper. Patients were informed about the purpose of the component of nursing documentation and their rights. The response rate of patients who came to therapy was $100 \%$. Interviewing at the department was conducted by two specially trained nurses who were responsible for administering therapy as well, thus reducing variability in data collection. Sample control and data collection were performed on all patients with advanced non-small cell lung cancer included in the study by the authorized specially trained nurses. The average duration of completing the questionnaire was between 10 and 15 minutes.
The component was created by the author of this paper and is based on real needs as well as experiences in literature. The component aimed to design monitoring of the general and nutritional status of oncology patients to monitor and possibly predict the patient's future condition, improve or deteriorate concerning nutritional status, and the possibility of taking the necessary preventive and curative measures (41).

The component included the collection of the following data: data on disease stage and cancer type, data on the type and stage of treatment - treatment line and cycles, demographic characteristics of subjects (age and gender), skinfold thickness, standardized screening using Nutritional Risk Screening 2002 questionnaire $(42,43)$, vital signs - blood pressure (mm Hg), heart rate and number of respirations/ minutes, body weight in $\mathrm{kg}$, body height in $\mathrm{cm}$, body mass index (BMI) - calculated in the following equation: $\mathrm{BMI}=$ bodyweight $\div$ [height $]^{2}$, i.e. corrected for age $=\left(\mathrm{m} / \mathrm{h}^{2}\right)-(\mathrm{a}-30) / 10 ; 30<\mathrm{a}<75$. where $a$ is $=$ age. Furthermore, for comparison, we categorize levels of malnutrition based on BMI: malnutrition (category 1 ) $\mathrm{BMI}<18.5$, ideal weight (category 2) BMI 18.5 - 24.9, overweight (category 3) BMI 25.0 - 29.9, obesity grade 1 (category 4) BMI 30.0 - 34.9. Subjective assessment of the patient identified conditions of fatigue and nausea, food intake and further analyzed the reasons for reduced nutrition (if it occurred). A subjective assessment of nausea and vomiting was followed for the first five days after chemotherapy. A visual analogue scale (VAS) was used to assess pain. The VAS scale has a range of 0-10, where the lowest value of 0 indicates no pain, and the highest value of 10 indicates unbearable pain $(41,44,45)$.

The survey took place every time the respondents arrived for therapy. The time interval between therapies was three weeks. Each time the respondents arrived, a new list of assessments and monitoring was opened. Weight measurement was always carried out using the same scale. The respondents were in their clothes when weighed, without a jacket or shoes. Skinfold thickness was measured with an electronic calliper (Finesse), at the right upper arm. 


\section{Ethics}

The component of nursing documentation was introduced as mandatory nursing documentation at the Department for respiratory diseases Jordanovac, University Hospital Center Zagreb, Croatia, in 2013. The Croatian Chamber for nurses as a regulatory body approved a component of nursing documentation, the implementation and analysis of the documentation was carried out according to the highest ethical standards of the nursing profession. The Ethics Committee of the Croatian Chamber of Nurses approved the study on the basis that it was a non-interventional study. The data were collected as part of the usual nursing history, there was no need for patients to sign a separate informed consent to participate in the study.

\section{Statistics}

The data collected were analyzed by statistical suite Statistica 16.0, licensed at the University Computing Center (SRCE, site:0082452005), and Microsoft Excel with Office Version 2010.

Differences between studied subgroups (women and men, lines of therapy, risks of malnutrition) were analyzed using descriptive statistic (frequency distributions and contingency tables), while the correlations were analyzed using bivariate (Pearson) correlation analysis.

\section{Results}

A total of 76 lung cancer patients participated in the study, of which 58 (76.3\%) men and 18 (23.7\%) women. 76 subjects had an average of 5 visits to our department, the total number of measurements was 417. The age range of subjects was between 47 and 89 years of age, with an average age of 65 years. The central value or median is 65 , while the most common value or mode is 62 .

Using descriptive analysis, we confirmed that the highest percentage of measurements of subjects in the study was during the first line of treatment (59.3\%) while the lowest percentage of measure- ments during the study was in the fourth line of patient treatment (1.7\%). The percentage of measurements observed during reevaluation between treatment lines was $15.9 \%$. The central value is 1 while the mode is also 1.

When examining body mass index, we ranked patients by category at each measurement. From overall 417 measurements, $44.8 \%$ of patients had an ideal weight, $37.4 \%$ were overweight and $14.6 \%$ obese. To assess the nutritional status of healthy individuals the calculation of BMI is usually used. This is a relatively precise measure of body mass and is, therefore, most commonly used for health risk assessment (Table 1).

\section{Table 1. Gender/BMI (first measurement)}

\begin{tabular}{cccc} 
Gender & \multicolumn{3}{c}{ BMI } \\
\cline { 2 - 4 } F & $0 \%$ & $50 \%$ & $50 \%$ \\
M & $3.4 \%$ & $44.8 \%$ & $51.7 \%$ \\
\hline
\end{tabular}

In the study, we conducted more detailed descriptive tests and compared the relationship of nutritional status with other measured and collected parameters. In each table, we have paired the nutritional status with another parameter to take a more detailed look at the distribution schedule (Table 2).

\begin{tabular}{|c|c|c|}
\hline \multirow{2}{*}{ BMI } & \multicolumn{2}{|c|}{ Nutritional status } \\
\hline & Severe risk & Mild malnutrition \\
\hline Malnutrition & $8.3 \%$ & $0 \%$ \\
\hline Ideal weight & $62.8 \%$ & $34.1 \%$ \\
\hline $\begin{array}{l}\text { Excessive weight } \\
+ \text { Obesity }\end{array}$ & $28.9 \%$ & $65.69 \%$ \\
\hline
\end{tabular}

$62.8 \%$ of subjects of ideal body weight were at severe risk of malnutrition and $65.9 \%$ of overweight subjects had mild malnutrition.

According to the data obtained, $3.1 \%$ of patients were malnourished at some point of the study, while none of the patients was in the category of severe obesity by body weight index. The average body mass index of the 


\begin{tabular}{c|cccc|}
\hline \multicolumn{5}{c}{ Table 3. Age/Weight loss (first and cumulative measurement) } \\
\hline Age & \multicolumn{4}{c|}{ Weight loss/weight gain (kg) } \\
\hline $45-69$ & From -30 to -10 & From -9 to -1 & 0 & From +1 to +6 \\
\hline $70+$ & $12.7 \% / 21.7 \%$ & $56.3 \% / 40.1 \%$ & $21.8 \% / 10.9 \%$ & $9 \% / 27.1 \%$ \\
\hline & $19.1 \% / 33.5 \%$ & $47.7 \% / 24 \%$ & $28.6 \% / 19.0 \%$ & $4.8 \% / 23.8 \%$ \\
\hline
\end{tabular}

patient corresponds to the category of ideal weight. The median body mass index is 25.24 , which corresponds to excessive weight, while the mode is 20.30 .

When included in the study, all subjects were measured, the subject with the lowest body weight weighed 47 kilograms while the subjects with the highest weight weighed 123 kilograms. The average weight of the subjects was 76.27 kilograms. The central value was 74 , while the mode was 81 , which is the most common recorded weight of subjects (4.3\%).

In the first measurement, weight gain was only $9 \%$, while the cumulative measurement increases the proportion of subjects who gained weight to $27 \%$. A positive shift is seen in each category except in the category of subjects who in the first measurement had a loss greater than $10 \mathrm{~kg}$ (Table 3 ).

By analyzing the nutritional status of patients as opposed to body mass index, values were obtained in only two categories (mild malnutrition and severe risk) and $62.6 \%$ of subjects were in the category of mild malnutrition, in the severe risk category, 37.4\% of subjects, while none were in the risk-free category. $67.9 \%$ of subjects who had a reduced diet during the study were at severe risk of malnutrition. In the same way, subjects who did not report reduced food intake during the study were more slightly malnourished at $89.3 \%$.

$82.1 \%$ of subjects (45-69 years of age) reported decreased food intake compared to $66.7 \%$ of subjects (70+ years of age). The study carried out 417 measurements, regardless of the age group, $32.1 \%$ reported reduced food intake and $67.9 \%$ of respondents said they did not reduce food intake. In the study group who reported that they had reduced food intake, 134 measurements were performed, the most common reasons for reduced food intake are listed in Table 4.

\begin{tabular}{|c|c|}
\hline Reason & $\%$ \\
\hline $\begin{array}{c}\mathrm{N} \\
\text { No appetite } \\
\text { Fatigue/weakness } \\
\text { Pain } \\
\text { Nausea } \\
\text { Vomiting } \\
\text { Constipation/Diarrhoea }\end{array}$ & $\begin{array}{c}134^{\star} \\
37.7 \\
31.2 \\
24.6 \\
22.9 \\
19.9 \\
7.9\end{array}$ \\
\hline
\end{tabular}

Throughout the study, lung cancer patients on a scale of 0 to 10 (where number 0 indicates a pain-free condition and number ten the highest possible level of pain) indicated the current feeling of pain at each measurement. During the study, most of the subjects reported no existence of pain (59.5\%), while no subject reported the highest level of pain (Table 5).

Table 5. Distribution of pain frequency

\begin{tabular}{ccc}
\hline VAS result & $\mathbf{N}$ & $\%$ \\
\hline 0 & 248 & 59.5 \\
\hline 1 & 8 & 1.9 \\
\hline 2 & 35 & 8.4 \\
3 & 40 & 9.6 \\
\hline 4 & 13 & 3.1 \\
\hline 5 & 39 & 9.4 \\
6 & 9 & 2.2 \\
\hline 7 & 14 & 3.4 \\
\hline 8 & 6 & 1.4 \\
\hline 9 & 5 & 1.2 \\
\hline 10 & 0 & 0 \\
\hline Total & 417 & 100 \\
\hline
\end{tabular}

Using a bivarious correlation test, we examined the association between the nutritional status of lung cancer patients and the loss of their body mass during the study. All tests were carried out at the risk 
level of $5 \%(p<.05)$. We found that there was a high interconnection between the subjects' weight loss and their nutritional status $(r=0.464 ; p<0.000)$. Such a high association was to be expected given that weight loss itself is indicative of the degree of nutritional status. We also checked the association between the subjects' weight loss and lack of appetite. We found that there was a relatively high negative association between the two factors $(r=-0.370 ; p<0.001)$. The negative association, in this case, indicates that if there is reduced food intake, there is also weight loss. In the same way, if there is no reduced food intake, there is less weight loss. Through further testing, we looked at the possible link between the lines of treatment that lung cancer patients underwent through the research period and the possible lack of appetite. We found that there was no statistically significant association between treatment lines and the occurrence of the lack of appetite. By testing the association between the number of treatment cycles and reduced food intake of subjects, we did not find a significant statistical correlation and had to determine that the two parameters were not interdependent. Among other things, we were interested in whether there was a statistically significant association between the subjects' body mass index and their nutritional status. The results show that there is a relatively high association between these two factors ( $r=0.376 ; p<0.000)$. These results were expected since the body mass index directly affected the patients' nutritional status. By testing the association between the nutritional status of subjects and the number of cycles of chemotherapy in treatment during the study, it was shown that there was a weak correlation between these two factors $(r=0.098 ; p<0.046)$. Even though the association is weak the findings nonetheless show how nutritional status and treatment cycle are interdependent. By looking at the parameters collected, we also tested the association between nutritional status and the thickness of the skin folds and found that there was a positive high association between the two parameters $(r=0.410 ; p<0.000)$ - the higher the thickness of the skin folds, the higher the degree of nutritional status.

\section{Discussion}

Lung cancer has the highest mortality rate in the world (46), with a poor survival prognosis, 16\% survival in 5 years $(47,48)$. In Croatia, the incidence by type of cancer, the cancer of trachea, bronchial and lungs is in the second most common type of cancer in men and the third in women. According to the latest data from the Cancer Registry in 2017, 3235 (2232 men/1003 women) patients with tracheal, bronchial and lung cancer were diagnosed (1).

It is interesting to keep track of how the number of women suffering from bronchial, tracheal and lung cancers is growing worldwide, and we are unfortunately seeing this trend in the Republic of Croatia. In 2013, according to the data from the Department for respiratory diseases Jordanovac, University Hospital Center Rebro, Zagreb, Croatia, we also recorded an increase in the proportion of women suffering from tracheal, bronchial and lung cancer the proportion of men $75 \%$, and women $25 \%$, while in 2009 , the proportion of men was $77 \%$ and women $23 \%$. The gender distribution of the sample coincides with the distribution of patients by gender who underwent oncological treatment at the Department for respiratory diseases Jordanovac, University Hospital Center Rebro, Zagreb, Croatia, in 2013.

The calculation of BMI is used to assess the nutritional status of healthy individuals. This is a relatively precise measure of body mass and is, therefore, most commonly used to assess health risks. In our survey, $44.8 \%$ of respondents had an ideal body mass and $52 \%$ higher than ideal. By correlation between body mass index and nutritional status, $62.8 \%$ of subjects of ideal body weight had a severe risk of malnutrition and $65.9 \%$ of overweight subjects were mildly malnourished. The conclusion is that BMI is not necessarily relevant or sufficient to assess the nutritional status of lung cancer patients, which corresponds to the opinion of other authors who state that in the case of cancer patients BMI is not a valid indicator for assessing nutritional status. According to the results obtained by our study, BMI was not a relevant indicator for assessing nutritional status in lung cancer patients older than 65 (49).

Weight loss is common in oncology patients, it may be caused by various factors such as mucositis, dys- 
phagia, loss of appetite and metabolic abnormalities (50). During our study on weight loss or gain, a positive shift in the course of treatment was observed in most subjects, except for subjects who had already had a drop in body weight greater than 10 kilograms at the first measurement. In the age group between 45 and 69 years, weight loss greater than 10 kilograms was observed in $12.7 \%$ of subjects at the first measurement, by cumulative measurement during treatment it increased to $21.7 \%$. In the age group $70+, 19.1 \%$ of subjects had weight loss at the first measurement, by cumulative measurement during treatment it increased to $33.5 \%$. Age-group differences are not surprising. With age, metabolic, physiological and biochemical processes change, and these changes have an adverse effect on nutritional status in older people. The sharpness of taste, smell, loss of teeth, and thus decrease the possibility of enjoying food. With ageing the body's composition changes, muscle mass decreases and metabolism slows down (49). This data indicates the importance of timely nutritional support to avoid irreversible cachexia. It is assumed that adequate caloric intake by enteral or parenteral route would be the optimal approach in addressing weight loss in oncology patients. In the terminal stages of lung cancer, the nutritional supplement has a non-beneficial effect and it is not recommended (50-52).

During our study, collected data shows that weight loss less than 10 kilograms at the first measurement and by cumulative measurements record a decrease in the proportion of weight loss during treatment. It was interesting to note that a significant decrease in body weight precedes disease progression and weight loss can be seen in part as a possible diagnostic parameter in the monitoring of lung cancer patients. Due to the small number of respondents in this sample, we did not determine the statistical significance of this occurrence. Weight loss is an important criterion for diagnosing pre-cachexia and cachexia and is a negative prognostic survival sign for cancer patients. Dewys et al. conducted a study on a sample of 3,047 lung cancer patients to determine the association between weight loss and chemotherapy treatment. They found that weight loss was correlated with decreased general patient status, reduced median survival, reduced rate of chemotherapy response, and the frequency of weight loss increased by increasing the number of metastatic changes (39).
Malnutrition is defined as the nutritional status in which energy, proteins or other nutritional ingredients are in deficit, their deficiency leads to visible and measurable adverse side effects in tissue, function and clinical outcomes. Malnutrition occurs in $\mathbf{4 0}$ to $80 \%$ lung cancer patients $(50,53-55)$, unrelated to the cause leads to a decrease in quality of life (50,56-59), lower response to chemotherapy treatment $(39,56,60)$, increased toxicity related to the chemotherapy treatment (61-63), reduces the benefits of pharmacological therapy $(60,61)$, prolongs postoperative recovery $(64,65)$, reduces survival $(39,56,66)$ and it is the leading cause of mortality in the advanced stage of the disease (50,53-55).

Anorexia has been linked to reduced food intake, weight loss and can lead to cancer anorexia-cachexia syndrome (CACS) (67). CACS was identified as a risk factor for reduced quality of life and poorer survival prognosis. Most lung cancer patients will develop CACS, for this reason, it is extremely important to promptly implement early interventions in patients with cachexia. Early nutritional and pharmacological interventions as well encouragement on physical activity are used in the prevention of the occurrence of CACS $(68,69)$. Pharmacological interventions in CACS successfully reduce or resolve a large proportion of symptoms in lung cancer patients (pain, dyspnea, nausea/vomiting, fatigue) (28), improve appetite, reduce systemic inflammation and improve anabolic metabolism (69-72).

Pain is a common problem that significantly affects the reduction in food intake. ECOG Performance Status, weight loss, dyspnea, fatigue and pain are significant prognostic indicators, associated with reduced quality of life and with a lower survival prognosis $(73,74)$. A prospective study was conducted on a sample of 301 patients with non-small cell lung cancer to determine the frequency, characteristics and treatment of chronic malignant pain. The intensity of pain is determined by a visual analogue scale (VAS). Most patients experienced moderate and high-intensity pain ( $47 \%$ and $26 \%$ ), and only $5 \%$ of patients had sufficient analgesic therapy, while more than $90 \%$ of patients were treated outside the recommended therapeutic guidelines (75).

In our sample by examining the pain frequency distribution of subjects, according to the visual analogue scale mild pain (VAS $<3$ ) was experienced by $10.3 \%$ of subjects, mild to medium pain (VAS 3-6) by $24.3 \%$ of subjects, and severe pain (VAS more than 6 ) by $6 \%$ of 
subjects. No pain was reported in $59.5 \%$ of subjects, and no subjects indicated pain intensity VAS 10. A total of $24.6 \%$ of subjects reported pain as a reason for reduced food intake, which corresponds to the proportion of subjects who had inadequately controlled pain, VAS greater than 5 . Comparatively to the above-mentioned study, we see a significant shift in the control of malignant pain in the study population.

Nutritional deficiency and the presence of pain are common in lung cancer patients, especially in the advanced-stage disease. Chabowski et al. conducted a study on a sample of 257 lung cancer patients to determine the association between pain perception, nutritional status and level of anxiety, depression. $23 \%$ of patients were malnourished, $33 \%$ at risk of malnutrition and $44 \%$ with a normal nutritional status. $65 \%$ of subjects had symptoms of depression and $65 \%$ of anxiety. A significant negative correlation was present between nutritional status and pain as well as between nutritional status, anxiety and depression (76).

The prevalence of nutritional status disorders, the intensity of somatic symptoms and psychological stress are common in lung cancer patients. The indication for early intervention measures (psychological and pharmacological) is extremely important in lung cancer patients who have an increased risk of malnutrition, significant levels of depression, anxiety and pain (76). Turcott et al. documented a link between well-controlled pain with opioids and improvements in nutritional status. Besides, with well-controlled pain, cancer patients had increased food intake, a better quality of life, emotional and social functioning, better pain control and sleep. With adequate opioid use, anorexia is less common in lung cancer patients compared to patients in the control group without opioid use (72).

The nutritional status disorder leads to malnutrition, which is common in oncology patients and the leading cause of a decrease in quality of life and survival. We assumed at the beginning of the study that the leading causes of food intake reduction would be the most frequent side effects of chemotherapy treatments such as nausea and vomiting, but after analyzing the data we noticed that pain was a more common cause of food intake reduction. Based on the data obtained from our sample compared to the other studies in the discussion, we can conclude that assessment and well-controlled pain is necessary for maintaining adequate nutritional status in lung cancer patients.

\section{Conclusion}

Initial assessment and monitoring of nutritional status must be a mandatory and inseparable part of the care of lung cancer patients. The component of nursing documentation (41) contains all parameters relevant for assessing and monitoring the nutritional status of lung cancer patients. By systematically monitoring the nutritional status of patients, we can monitor and analyze the frequency and reasons for the occurrence of individual symptoms, enabling their timely detection and adequate timely intervention.

Based on the research and the results obtained, the following conclusions can be drawn: body mass index is associated with the risk of malnutrition but is not a sufficient indicator for assessing the nutritional status of cancer patients and the elderly. Although we expected an association between the stage of chemotherapy and reduced food intake, no association between the number of oncology cycles and the occurrence of reduced food intake was demonstrated. There is a poor correlation between nutritional status and treatment lines, which can be explained by the sample size and individual characteristics of the subjects. Initial weight loss greater than 10 kilograms in both age categories, and in particularly the category $70+$, was associated with a reduced response to nutritional support, and during differentiated treatment weight loss continued. By continuous monitoring of pain intensity good control of malignant pain in the study population was achieved, which is an important data in the assessment of nutritional status since poorly controlled pain in $24 \%$ of subjects is the reason for reduced food intake.

\section{Acknowledgements}

Thanks to colleagues and associates at the Department for respiratory diseases Jordanovac, University Hospital Center Rebro, Zagreb, Croatia, especially Ljiljana Samardžić and Tatjana Topalušić for the support and collected data that have been analyzed in this paper. Thanks to Vanesa Benković for her support and assistance in statistical processing and analysis of the data collected. 


\section{References}

1. Hrvatski zavod za javno zdravstvo. Incidencija raka u Hrvatskoj - Cancer incidence in Croatia. 2017. Available from: https://www.hzjz.hr/wp-content/ uploads/2017/01/Bilten-2017-final.pdf Croatian.

2. Brambilla E, Travis WD. Lung cancer. In: Stewart BW, Wild CP (Eds). World Cancer Report. Lyon: World Health Organization; 2014.

3. Duma N, Santana-Davila R, Molina JR. Non-Small Cell Lung Cancer: Epidemiology, Screening, Diagnosis, and Treatment. Mayo Clin Proc. 2019;94(8):1623-40.

4. Siegel RL, Miller KD, Jemal A. Cancer statistics, 2020. CA Cancer J Clin. 2020;70(1):7-30.

5. Midthun DE. Overview of the risk factors, pathology, and clinical manifestations of lung cancer. Available from: https://www.uptodate.com/contents/overviewof-the-risk-factors-pathology-and-clinical-manifestations-of-lung-cancer Accessed: 12.05.2020.

6. Midthun DE. Overview of the initial treatment and prognosis of lung cancer. Available from: https://www.uptodate.com/contents/overview-of-the-initial-treatmentand-prognosis-of-lung-cancer Accessed: 12.05.2020.

7. Beliveau R, Gingras D. Problem raka. U: Uskoković D, urednik. Hranom protiv raka. Zagreb: Mozaik knjiga; 2007.

8. Chute CG, Greenberg ER, Baron J, Korson R, Baker J, Yates J. Presenting conditions of 1539 population-based lung cancer patients by cell type and stage in New Hampshire and Vermont. Cancer. 1985;56(8):2107-11.

9. Hyde $L$, Hyde Cl. Clinical manifestations of lung cancer. Chest. 1974;65(3):299-306.

10. Kocher F, Hilbe W, Seeber A, Pircher A, Schmid T, Greil $R$, et al. Longitudinal analysis of 2293 NSCLC patients: a comprehensive study from the TYROL registry. Lung Cancer. 2015;87(2):193-200.

11. Kuo CW, Chen YM, Chao JY, Tsai CM, Perng RP. Nonsmall cell lung cancer in very young and very old patients. Chest. 2000;117(2):354-7.

12. Chen $\mathrm{HC}$, Jen $\mathrm{YM}$, Wang $\mathrm{CH}$, Lee JC, Lin YS. Etiology of vocal cord paralysis. ORL J Otorhinolaryngol Relat Spec. 2007;69(3):167-71.

13. Ramadan HH, Wax MK, Avery S. Outcome and changing cause of unilateral vocal cord paralysis. Otolaryngol Head Neck Surg. 1998;118(2):199-202.

14. Sahn SA. Malignancy metastatic to the pleura. Clin Chest Med. 1998;19(2):351-61.

15. Kosmidis P, Krzakowski M; ECAS Investigators. Anemia profiles in patients with lung cancer: what have we learned from the European Cancer Anaemia Survey (ECAS)? Lung Cancer. 2005;50(3):401-12.

16. Hiraki A, Ueoka H, Takata I, Gemba K, Bessho A, Segawa $Y$, et al. Hypercalcemia-leukocytosis syndrome associated with lung cancer. Lung Cancer. 2004;43(3):301-7.
17. Kasuga I, Makino S, Kiyokawa H, Katoh H, Ebihara $Y$, Ohyashiki K. Tumor-related leukocytosis is linked with poor prognosis in patients with lung carcinoma. Cancer. 2001;92(9):2399-405.

18. Aoe K, Hiraki A, Ueoka H, Kiura K, Tabata M, Tanaka $M$, et al. Thrombocytosis as a useful prognostic indicator in patients with lung cancer. Respiration. 2004;71(2):170-3.

19. Hamilton W, Peters TJ, Round A, Sharp D. What are the clinical features of lung cancer before the diagnosis is made? A population based case-control study. Thorax. 2005;60(12):1059-65.

20. Chernow B, Sahn SA. Carcinomatous involvement of the pleura: an analysis of 96 patients. Am J Med. 1977;63(5):695-702.

21. Hoang $T, X u$ R, Schiller JH, Bonomi P, Johnson DH. Clinical model to predict survival in chemonaive patients with advanced non-small-cell lung cancer treated with third-generation chemotherapy regimens based on eastern cooperative oncology group data. J Clin Oncol. 2005;23(1):175-83.

22. Blackstock AW, Herndon JE 2nd, Paskett ED, Perry MC, Graziano SL, Muscato JJ, et al. Outcomes among African-American/non-African-American patients with advanced non-small-cell lung carcinoma: report from the Cancer and Leukemia Group B. J Natl Cancer Inst. 2002;94(4):284-90.

23. Stanley KE. Prognostic factors for survival in patients with inoperable lung cancer. J Natl Cancer Inst. 1980;65(1):25-32.

24. Feinstein AR. Symptomatic patterns, biologic behavior, and prognosis in cancer of the lung. Practical application of boolean algebra and clinical taxonomy. Ann Intern Med. 1964;61:27-43.

25. Kawaguchi T, Takada M, Kubo A, Matsumura A, Fukai S, Tamura A, et al. Performance status and smoking status are independent favorable prognostic factors for survival in non-small cell lung cancer: a comprehensive analysis of 26,957 patients with NSCLC. J Thorac Oncol. 2010;5(5):620-30.

26. Sculier JP, Chansky K, Crowley JJ, Van Meerbeeck J, Goldstraw P; International Staging Committee and Participating Institutions. The impact of additional prognostic factors on survival and their relationship with the anatomical extent of disease expressed by the 6th Edition of the TNM Classification of Malignant Tumors and the proposals for the 7th Edition. J Thorac Oncol. 2008;3(5):457-66.

27. Del Fabbro $E$. Assessment and management of chemical coping in patients with cancer. J Clin Oncol. 2014;32(16):1734-8.

28. Bruera $E$, Dev R. Overview of managing common non-pain symptoms in palliative care. Available from: https://www.uptodate.com/contents/overview-ofmanaging-common-non-pain-symptoms-in-palliativecare Accessed:12.05.2020. 
29. Sweeney MP, Bagg J. The mouth and palliative care. Am J Hosp Palliat Care. 2000;17(2):118-24.

30. De Conno F, Sbanotto A, Ripamonti C, Ventafridda V. Mouth Care. In: Doyle D, Hanks GWC, MacDonald N (Eds). Oxford Textbook of Palliative Medicine, 3rd ed. Oxford University Press; 2004. p. 673.

31. Teunissen SC, Wesker W, Kruitwagen C, de Haes HC, Voest EE, de Graeff A. Symptom prevalence in patients with incurable cancer: a systematic review. J Pain Symptom Manage. 2007;34(1):94-104.

32. Oncology. Clin Privil White Pap. 2000;(142):1-12.

33. Tchekmedyian NS. Costs and benefits of nutrition support in cancer. Oncology (Williston Park). 1995;9(11 Suppl):79-84.

34. Jatoi $A$, Loprinzi CL. Pathogenesis, clinical features, and assessment of cancer cachexia. Available from: https://www.uptodate.com/contents/pathogenesisclinical-features-and-assessment-of-cancer-cachexia Accessed: 12.05.2020.

35. Davis MP, Dickerson D. Cachexia and anorexia: cancer's covert killer. Support Care Cancer. 2000;8(3):180-7.

36. Fearon K, Strasser F, Anker SD, Bosaeus I, Bruera E, Fainsinger RL, et al. Definition and classification of cancer cachexia: an international consensus. Lancet Oncol. 2011;12(5):489-95.

37. Evans W], Morley JE, Argilés J, Bales C, Baracos V, Guttridge $D$, et al. Cachexia: a new definition. Clin Nutr. 2008;27(6):793-9.

38. Blum D, Strasser F. Cachexia assessment tools. Curr Opin Support Palliat Care. 2011;5(4):350-5.

39. Dewys WD, Begg C, Lavin PT, Band PR, Bennett JM, Bertino JR, et al. Prognostic effect of weight loss prior to chemotherapy in cancer patients. Eastern Cooperative Oncology Group. Am J Med. 1980;69(4):491-7.

40. Vranešić Bender D, Krznarić Ž. Malnutricija - pothranjenost bolničkih pacijenata. Medicus. 2008;17(1_Nutricionizam):71-9. Croatian.

41. Karabatić S. Inicijalna procjena i praćenje nutritivnog statusa bolesnika s rakom pluća. [diplomski rad] Zagreb: Sveučište u Zagrebu Medicinski fakultet; 2014. Croatian.

42. Krznarić Z, Bender DV, Kelecić DL, Reiner Z, Roksandić ST, Kekez D, et al. Hrvatske smjernice za prehranu osoba starije dobi, dio II--klinicka prehrana. Lijec Vjesn. 2011;133(9-10):299-307. Croatian.

43. Kondrup J, Allison SP, Elia M, Vellas B, Plauth M; Educational and Clinical Practice Committee, European Society of Parenteral and Enteral Nutrition (ESPEN). ESPEN guidelines for nutrition screening 2002. Clin Nutr. 2003;22(4):415-21.

44. Scott J, Huskisson EC. Graphic representation of pain. Pain. 1976;2(2):175-84.

45. Carlsson AM. Assessment of chronic pain. Aspects of the reliability and validity of the visual analogue scale. Pain. 1983;16(1):87-101.

46. Torre LA, Bray F, Siegel RL, Ferlay J, Lortet-Tieulent J, Jemal A. Global cancer statistics, 2012. CA Cancer J Clin. 2015;65(2):87-108.
47. Arrieta 0, Carmona A, Ramírez-Tirado LA, FloresEstrada D, Macedo-Pérez EO, Martínez-Hernández JN, et al. Survival of Patients with Advanced Non-Small Cell Lung Cancer Enrolled in Clinical Trials. Oncology. 2016;91(4):185-93.

48. Arrieta Arrieta O, Guzmán-de Alba E, Alba-López LF, Acosta-Espinoza A, Alatorre-Alexander J, AlexanderMeza JF, et al. Consenso nacional de diagnóstico y tratamiento del cáncer de pulmón de células no pequeñas. Rev Invest Clin. 2013;65 Suppl 1:S5-84. Spanish.

49. Kovačević A, Prlić N. Nutritivni status osoba starijih od 65 godina. SEEHSJ. 2011;1(1):24-31.

50. Jatoi $A$, Loprinzi $C L$. The role of parenteral and enteral/ oral nutritional support in patients with cancer. Available from: https://www.uptodate.com/contents/the-role-of-parenteral-and-enteral-oral-nutritional-supportin-patients-with-cancer Accessed: 12.05.2020.

51. Koretz RL, Avenell A, Lipman TO, Braunschweig CL, Milne AC. Does enteral nutrition affect clinical outcome? A systematic review of the randomized trials. Am J Gastroenterol. 2007;102(2):412-29.

52. Koretz RL, Lipman TO, Klein S; American Gastroenterological Association. AGA technical review on parenteral nutrition. Gastroenterology. 2001;121(4):970-1001.

53. Miyauchi $E$, Inoue $A$, Usui $K$, Sugawara $S$, Maemondo $M$, Saito $\mathrm{H}$, et al. Phase II Study of Modified Carboplatin Plus Weekly Nab-Paclitaxel in Elderly Patients with NonSmall Cell Lung Cancer: North Japan Lung Cancer Study Group Trial 1301. Oncologist. 2017;22(6):640-e59.

54. Lees J. Incidence of weight loss in head and neck cancer patients on commencing radiotherapy treatment at a regional oncology centre. Eur J Cancer Care (Engl). 1999;8(3):133-6.

55. Nitenberg G, Raynard B. Nutritional support of the cancer patient: issues and dilemmas. Crit Rev Oncol Hematol. 2000;34(3):137-68.

56. Andreyev HJ, Norman AR, Oates J, Cunningham D. Why do patients with weight loss have a worse outcome when undergoing chemotherapy for gastrointestinal malignancies? Eur J Cancer. 1998;34(4):503-9.

57. Hammerlid E, Wirblad B, Sandin C, Mercke C, Edström S, Kaasa $S$, et al. Malnutrition and food intake in relation to quality of life in head and neck cancer patients. Head Neck. 1998;20(6):540-8.

58. Ravasco P, Monteiro-Grillo I, Vidal PM, Camilo ME. Cancer: disease and nutrition are key determinants of patients' quality of life. Support Care Cancer. 2004;12(4):246-52.

59. Tian J, Chen JS. Nutritional status and quality of life of the gastric cancer patients in Changle County of China. World J Gastroenterol. 2005;11(11):1582-6.

60. Salas S, Deville JL, Giorgi R, Pignon T, Bagarry D, Barrau $K$, et al. Nutritional factors as predictors of response to radio-chemotherapy and survival in unresectable squamous head and neck carcinoma. Radiother Oncol. 2008;87(2):195-200. 
61. Barret M, Malka D, Aparicio T, Dalban C, Locher C, Sabate JM, et al. Nutritional status affects treatment tolerability and survival in metastatic colorectal cancer patients: results of an AGEO prospective multicenter study. Oncology. 2011;81(5-6):395-402.

62. Aslani A, Smith RC, Allen BJ, Pavlakis N, Levi JA. The predictive value of body protein for chemotherapy-induced toxicity. Cancer. 2000;88(4):796-803.

63. van Eys J. Effect of nutritional status on responses to therapy. Cancer Res. 1982;42(2 Suppl):747-53.

64. Jagoe RT, Goodship TH, Gibson GJ. The influence of nutritional status on complications after operations for lung cancer. Ann Thorac Surg. 2001;71(3):936-43.

65. Rey-Ferro M, Castaño R, Orozco O, Serna A, Moreno A. Nutritional and immunologic evaluation of patients with gastric cancer before and after surgery. Nutrition. 1997;13(10):878-81.

66. Senesse P, Assenat E, Schneider S, Chargari C, Magné N, Azria $D$, et al. Nutritional support during oncologic treatment of patients with gastrointestinal cancer: who could benefit? Cancer Treat Rev. 2008;34(6):568-75.

67. Nasrah R, Kanbalian M, Van Der Borch C, Swinton N, Wing $S$, Jagoe RT. Defining the role of dietary intake in determining weight change in patients with cancer cachexia. Clin Nutr. 2018;37(1):235-41.

68. Cardona AF, Rojas L, Wills B, Arrieta O, Carranza H, Vargas C, et al. Pemetrexed/Carboplatin/Bevacizumab followed by Maintenance Pemetrexed/Bevacizumab in Hispanic Patients with Non-Squamous Non-Small Cell Lung Cancer: Outcomes according to Thymidylate Synthase Expression. PLoS One. 2016;11(5):e0154293.

69. Ming-Hua C, Bao-Hua Z, Lei Y. Mechanisms of anorexia cancer cachexia syndrome and potential benefits of traditional medicine and natural herbs. Curr Pharm Biotechnol. 2016;17(13):1147-52.
70. Orozco-Morales M, Soca-Chafre G, Barrios-Bernal P, Hernández-Pedro N, Arrieta O. Interplay between Cellular and Molecular Inflammatory Mediators in Lung Cancer. Mediators Inflamm. 2016;2016:3494608.

71. Arrieta O, De la Torre-Vallejo M, López-Macías D, Orta D, Turcott J, Macedo-Pérez EO, et al. Nutritional Status, Body Surface, and Low Lean Body Mass/Body Mass Index Are Related to Dose Reduction and Severe Gastrointestinal Toxicity Induced by Afatinib in Patients With Non-Small Cell Lung Cancer. Oncologist. 2015;20(8):967-74.

72. Turcott JG, Del Rocío Guillen Núñez M, Flores-Estrada D, Oñate-Ocaña LF, Zatarain-Barrón ZL, Barrón F, et al. The effect of nabilone on appetite, nutritional status, and quality of life in lung cancer patients: a randomized, double-blind clinical trial. Support Care Cancer. 2018;26(9):3029-38.

73. Hauser CA, Stockler MR, Tattersall MH. Prognostic factors in patients with recently diagnosed incurable cancer: a systematic review. Support Care Cancer. 2006;14(10):999-1011.

74. Salpeter SR, Malter DS, Luo EJ, Lin AY, Stuart B. Systematic review of cancer presentations with a median survival of six months or less. J Palliat Med. 2012;15(2):175-85.

75. Pleština $S$. Učestalost, obilježja i liječenje kronične maligne boli u bolesnika s karcinomom pluća ne-malih stanica. [doktorska disertacija] Zagreb: Sveučilište u Zagrebu Medicinski fakultet; 2011. Croatian.

76. Chabowski M, Polański J, Jankowska-Polańska B, Janczak D, Rosińczuk J. Is nutritional status associated with the level of anxiety, depression and pain in patients with lung cancer? J Thorac Dis. 2018;10(4):2303-10. 


\section{INICIJALNA PROCJENA I PRAĆENJE NUTRITIVNOG STATUSA I MALIGNE BOLI U BOLESNIKA S RAKOM PLUĆA}

\section{Sažetak}

Uvod. Rak pluća jest kompleksna bolest i zahtijeva multidisciplinarni pristup kako bi se postigli što bolji rezultati u liječenju i povećala stopa preživljavanja uz istodobno očuvanje kvalitete života oboljelog. Nutritivni status bolesnika pokazao se važnim čimbenikom koji utječe na ishod i oporavak od bolesti ili ozljede. Postavljamo pitanje postoji li poveznica između nutritivnog statusa i maligne boli u bolesnika s rakom pluća.

Cilj. Provedeno je prospektivno istraživanje kako bi se utvrdila raspodjela ispitanika prema učestalosti bolova prema validiranoj vizualnoj analognoj skali (VAS), raspodjela ispitanika koji su prijavili smanjeni unos hrane i raspodjela čimbenika koji su doveli do smanjenog unosa hrane.

Metode. Istraživanje je provedeno na Zavodu za tumore pluća i sredoprsja Klinike za plućne bolesti Jordanovac Kliničkoga bolničkog centra Zagreb, na uzorku bolesnika s uznapredovalim rakom pluća nemalih stanica $(\mathrm{N}=76)$. u periodu od studenoga 2013. do lipnja 2014. Za procjenu boli primijenjen je validirani VAS. Za identifikaciju pacijenata s rizikom od pothranjenosti primijenjen je alat za provjeru prehrambenih rizika (NRS 2002). Za grubu procjenu količine masnog tkiva koristili smo se kaliperom. Praćenje bolesnika dokumentirano je u obliku sestrinske dokumentacije. Sastavnica sestrinske dokumentacije osmišljena je za praćenje prehrambenog stanja oboljelih od karcinoma i implementirana je na Odjelu za respiratorne bolesti Jordanovac kao potrebna do- kumentacija. Sastavnica je obuhvatila prikupljanje sljedećih podataka: stadij bolesti i tip karcinoma, tip i stadij liječenja, demografske karakteristike ispitanika, debljina kožnog nabora, standardizirani upitnik o pothranjenosti Nutritional NRS 20021, vitalni znakovi, tjelesna težina, tjelesna visina, indeks tjelesne mase, subjektivna procjena pacijenta; bol, umor i mučnina, razlozi smanjene prehrane.

Rezultati. Tijekom provedenog istraživanja izvedeno je 417 mjerenja: 1) 32,1\% ispitanika prijavilo je smanjeni unos hrane, a 67,9\% istaknulo kako nisu smanjivali redovitu prehranu; 2) najučestaliji uzroci smanjenog unosa hrane $u$ ispitanika su bili nedostatak apetita (37,7\%), prisutnost umora/slabosti (31,2\%) i prisutnosti boli (24,6 \%); 3) 59,5\% ispitanika prijavilo je nepostojanje boli, dok nijedan ispitanik nije prijavio postojanje najvećeg stupnja boli.

Zaključak. Redovitim praćenjem intenziteta boli ostvarena je dobra kontrola maligne boli kod ispitivane populacije, što je važan podatak kod procjene nutritivnog statusa. Činjenica je da je loše kontrolirana bol u $24 \%$ ispitanika razlog smanjenog unosa hrane.

Ključne riječi: rak pluća, nutritivni status, bol, sastavnica sestrinske liste 